\title{
PESANTREN DAN PELANGGARAN HAM (Studi Analisa Tentang Ta'zir dalam Pesantren Salafy)
}

\author{
Oleh: \\ Laila Ngindana Zulfa \\ Universitas Wahid Hasyim Semarang \\ lailangindana@unwahas.ac.id
}

\begin{abstract}
Abstrac
Human rights are basic rights that are inherent and universal in human beings. In Indonesia, human rights have been protected by the laws that originate and lead to "Pancasila". No one can interfere with human rights or eliminate its. In this contemporary era, many practitioners and education thinkers, who analyze about Ta'zir (A punishment) applied to Islamic boarding schools, especially in Islamic boarding schools with typology of salafy. Some people argue that Ta'zir is a form of human rights violations, others say there are not. In this discussion the author tries to provide an analysis related to Ta'zir which is a punishment given to students who violate the rules in the Islamic Boarding School, Is it included in the category of human rights violations that must be eliminated. Or is it just a learning method that aims to provide a deterrent effect on students who break the rules.
\end{abstract}

Keywords: Human Rights, Islamic Boarding School, Ta'zir.

\begin{abstract}
Abstrak
HAM merupakan hak dasar yang kodratnya melekat pada diri manusia dan bersifat universal serta langgeng. HAM di Indonesia dilindungi oleh UU yang bersumber serta bermuara pada Pancasila. Tidak ada satupun manusia yang boleh mengganggu ataupun menghilangkan hak asasi manusia (HAM). Banyak Praktisi dan pemikir pendidikan dizaman kontemporer ini yang menganalisa tentang Ta'zir (Sebuah hukuman) yang di terapkan pada pondok pesantren terutama pada pesantren yang ber-tipologi salafy. Sebagian berpendapat bahwa ta'zir merupakan salah satu bentuk pelanggaran HAM, sebagian lain mengatakan tidak terdapat pelanggaran HAM. Pada pembahasan ini penulis mencoba untuk memberikan analisa terkait Ta'zir yaitu sebuah hukuman yang diberikan kepada santri yang melanggar aturan dalam Pesantren, apakah termasuk dalam kategori pelanggaran HAM sehingga harus dihapuskan. Ataukah memang hanya sebuah metode pembelajaran yang bertujuan untuk memberikan efek jera pada santri pelanggar aturan.
\end{abstract}

Kata Kunci: HAM, Pesantren, $\mathrm{Ta}^{\prime}$ zir.

PROGRESS - Volume 8, No. 1, Juni 2020 


\section{A. Pendahuluan}

Hak Asasi merupakan unsur Penting yang melekat pada diri setiap manusia sejak mereka berada dalam kandungan sampai akhir hayatnya. Menurut Ketetapan MPR nomor XVII/MPR/1988, bahwa hak asasi manusia adalah hak-hak dasar yang melekat pada diri manusia secara kodrat, universal, dan abadi sebagai anugerah Tuhan Yang Maha Esa.

Tidak ada satupun dari manusia yang boleh mengganggu ataupun menghilangkan hak asasi manusia (HAM), yang telah diberikan oleh pemerintah kepada rakyatnya. Namun dalam kehidupan manusia, mereka saling berinteraksi antara satu dengan yang lainnya yang tidak jarang menimbulkan gesekan-gesekan antar individu dalam upaya pemenuhan HAM pada diri sendiri. Hal inilah yang kemudian dapat menimbulkan terjadinya pelanggaran HAM antara seorang individu terhadap individu lain, antara kelompok terhadap individu ataupun kelompok lain, ataupun sebaliknya.

Pesantren merupakan salah satu alternatif pendidikan yang berada di negara Indonesia ini. Menilik dari sejarahnya, ia merupakan suatu lembaga yang di dirikan untuk memenuhi kebutuhan penyiaran atau dakwah agama Islam di Nusantara. Seiring berjalannya waktu, pesantren memperbaharui dirinya dengan memasukkan model pembelajaran yang pro pemerintah, sehingga memberikan keragaman bentuk pendidikan di negara ini.

Terdapat berbagai tipologi pesantren, yang nantinya membedakan bentuk dan model pembelajaran yang ditawarkan oleh pesantren. Sehingga dengan bentuk kurikulum pembelajarannya, terdapat sebagian model pesantren yang menerapkan praktek pembelajaran dengan memberikan hukuman yang dianggap melanggar hak asasi manusia (HAM). Hal ini menjadi topik yang sangat menarik untuk diangkat 
mengingat sejak tahun 1999, pemerintah Indonesia memberikan perhatian yang sangat serius dalam hal penegakan hak asasi manusia (HAM).

\section{B. Sekilas tentang HAM}

1. Sejarah HAM di Indonesia

Gagasan tentang perlunya HAM sebenarnya sudah muncul pada pemerintahan Pada masa orde lama yang dikembangkan dalam sidang BPUPKI. Tokoh yang yang memperjuangkan agar HAM diatur secara luas dalam UUD 1945 dalam sidang ini adalah Mohammad Hatta dan Mohammad Sukiman. Akan tetapi, upaya mereka belum sepenuhnya berhasil dibuktikan dengan sedikit nilainilai HAM yang diatur dalam UUD 1945. Sementara itu, secara menyeluruh HAM diatur dalam Konstitusi RIS dan UUDS 1950.

Pada masa orde baru, pelanggaran HAM mencapai puncaknya. Hal ini terjadi karena HAM dianggap sebagai paham liberal (Barat) yang bertentangan dengan budaya timur dan Pancasila. Oleh sebab itu, HAM hanya diakui secara pesimis. Pada tahun 1993 Komisi Hak Asasi Manusia mulai dibentuk, namun komisi tersebut tidak berjalan dengan baik. Berbagai pelanggaran HAM terus terjadi, bahkan disinyalir terjadi pula berbagai pelanggaran HAM berat. Hal ini mendorong munculnya gerakan reformasi untuk mengakhiri kekuasaan orde baru. ${ }^{1}$

Masalah penegakan hak asasi manusia di Indonesia menjadi tekad dan komitmen yang kuat dari segenap komponen bangsa pada masa reformasi. Kemajuan ini ditandai dengan semakin terbukanya

1 http://www.zonasiswa.com/2014/07/sejarah-hak-asasi-manusia-ham.html dalam google diambil tanggal 30 Desember 2015. Baca Anhar Gonggong Dkk, Sejarah Pemikiran Hak-Hak Asasi Manusia Di Indonesia, (Jakarta: Depdikbud, 1995), hlm. 23 
iklim kebebasan dan munculnya berbagai dokumen HAM yang lebih baik. Dokumen-dokumen tersebut diantaranya UUD 1945 hasil amendemen, Tap MPR No. XVII/MPR/1998 tentang Hak Asasi Manusia, UU No. 39 tahun 1999 tentang Hak Asasi Manusia, dan UU No. 26 tahun 2000 tentang Pengadilan Hak Asasi Manusia.

Selain itu terdapat pembangunan Nasional tahun 2000-2004 (Propenas) dengan pembentukan kelembagaan yang berkaitan dengan HAM. Dalam hal kelembagaan telah dibentuk Komisi Nasional Hak Asasi Manusia dengan kepres nomor 50 tahun 1993, serta pembentukan Komisi Anti Kekerasan terhadap perempuan. ${ }^{2}$

Puncaknya ialah Pada tahun 2005, pemerintah meratifikasi dua instrumen yang sangat penting dalam penegakan HAM, yaitu Kovenan Internasional tentang Hak-Hak Ekonomi, Sosial dan Budaya (ICESCR) menjadi Undang-Undang No. 11 tahun 2005, dan Kovenan Internasional tentang Hak-Hak Sipil dan Politik (ICCPR) menjadi Undang-Undang No. 12 tahun 2005.

2. Ruang Lingkup HAM di Indonesia

Menurut undang-undang republik Indonesia no. 39 tahun 1999, bahwa yang dimaksud dengan hak asasi manusia adalah hak dasar yang secara kodrati melekat pada diri manusia, bersifat universal dan langgeng, oleh karena itu harus dilindungi, dihormati, dipertahankan, dan tidak boleh diabaikan, dikurangi, atau dirampas oleh siapapun.

Hak Asasi Manusia di Indonesia di lindungi oleh UU dan bersumber serta bermuara pada Pancasila. Artinya Hak Asasi Manusia mendapat jaminan kuat dari falsafah bangsa, yakni

2 https://edudetik.wordpress.com/2014/05/24/makalah-ham-pengertian-penyebabdan-contoh-kasus-pelanggaran-ham/ dalam google diambil pada tanggal 02 Januari 2016. Baca Kaelan, Pendidikan Pancasila, Edisi reformasi, (Yogyakarta: Paradigma, 2010), hlm. 89 
Pancasila. Yang dimaksud bermuara pada Pancasila adalah dalam rangka pelaksanaan hak asasi manusia haruslah memperhatikan garisgaris yang dijelaskan dalam ketentuan falsafah Pancasila. Bagi bangsa Indonesia, mendapatkan hak asasi manusia bukan berarti menjalankannya dengan bebas tanpa batas, melainkan harus memperhatikan ketentuan-ketentuan yang terkandung dalam pandangan hidup bangsa Indonesia, yaitu Pancasila.

Adapun hak-hak asasi manusia yang diatur dalam dalam Undang-Undang Nomor 39 Tahun 1999 tersebut antara lain sebagai berikut :

a. Hak untuk hidup di atur dalam Pasal 4 dan 9

b. Hak untuk berkeluarga di atur dalam Pasal 10

c. Hak untuk mengembangkan diri di atur dalam Pasal 11 sampai 16

d. Hak untuk memperoleh keadilan di atur dalam Pasal 17 sampai 19

e. Hak atas kebebasan pribadi di atur dalam Pasal 20 sampai 27

f. Hak atas rasa aman di atur dalam Pasal 28 sampai 35

g. Hak atas kesejahteraan di atur dalam Pasal 36 sampai 42

h. Hak turut serta dalam pemerintahan di atur dalam Pasal 43 sampai 44

i. Hak wanita di atur dalam Pasal 45 sampai 51

j. Hak anak di atur dalam Pasal 52 sampai 66

Untuk lebih jelasnya, Sebagaimana telah berhasil dirumuskan dalam naskah Perubahan Kedua UUD 1945, ketentuan mengenai hakhak asasi manusia telah mendapatkan jaminan konstitusional yang sangat kuat dalam Undang-Undang Dasar. Sebagian besar materi Undang-Undang Dasar ini sebenarnya berasal dari rumusan Undang- 
Undang yang telah disahkan sebelumnya, yaitu UU tentang Hak Asasi Manusia. Jika dirumuskan kembali, maka materi yang sudah diadopsikan ke dalam rumusan Undang-Undang Dasar 1945 mencakup 27 materi berikut:

a. Setiap orang berhak untuk hidup serta berhak mempertahankan hidup dan kehidupannya.

b. Setiap orang berhak membentuk keluarga dan melanjutkan keturunan melalui perkawinan yang sah.

c. Setiap anak berhak atas kelangsungan hidup, tumbuh dan berkembang serta berhak atas perlindungan dari kekerasan dan diskriminasi.

d. Setiap orang berhak bebas dari perlakuan yang bersifat diskriminatif atas dasar apapun dan berhak mendapatkan perlindungan terhadap perlakuan yang bersifat diskriminatif itu.

e. Setiap orang bebas memeluk agama dan beribadat menurut agamanya, memilih pendidikan dan pengajaran, memilih pekerjaan, memilih kewarganegaraan, memilih tempat tinggal di wilayah negara dan meninggalkannya, serta berhak kembali.

f. Setiap orang berhak atas kebebasan meyakini kepercayaan, menyatakan pikiran dan sikap, sesuai dengan hati nuraninya.

g. Setiap orang berhak atas kebebasan berserikat, berkumpul, dan mengeluarkan pendapat.

h. Setiap orang berhak untuk berkomunikasi dan memperoleh informasi untuk mengembangkan pribadi dan lingkungan sosialnya serta berhak untuk mencari, memperoleh, memiliki, menyimpan, mengolah, dan menyampaikan informasi dengan menggunakan segala jenis saluran yang tersedia. 
i. Setiap orang berhak atas perlindungan diri pribadi, keluarga, kehormatan, martabat, dan harta benda yang di bawah kekuasaannya, serta berhak atas rasa aman dan perlindungan dari ancaman ketakutan untuk berbuat atau tidak berbuat sesuatu yang merupakan hak asasi.

j. Setiap orang berhak untuk bebas dari penyiksaan atau perlakuan yang merendahkan derajat martabat manusia dan berhak memperoleh suaka politik dari negara lain.

k. Setiap orang berhak hidup sejahtera lahir dan batin, bertempat tinggal, dan mendapatkan lingkungan hidup yang baik dan sehat serta berhak memperoleh pelayanan kesehatan.

1. Setiap orang berhak mendapat kemudahan dan perlakuan khusus untuk memperoleh kesempatan dan manfaat yang sama guna mencapai persamaan dan keadilan.

m. Setiap orang berhak atas jaminan sosial yang memungkinkan pengembangan dirinya secara utuh sebagai manusia yang bermartabat.

n. Setiap orang berhak mempunyai hak milik pribadi dan hak milik tersebut tidak boleh diambil alih secara sewenang-wenang oleh siapapun.

o. Setiap orang berhak mengembangkan diri melalui pemenuhan kebutuhan dasarnya, berhak mendapat pendidikan dan memperoleh manfaat dari ilmu pengetahuan dan teknologi, seni dan budaya, demi meningkatkan kualitas hidupnya dan demi kesejahteraan umat manusia.

p. Setiap orang berhak untuk memajukan dirinya dalam memperjuangkan haknya secara kolektif untuk membangun masyarakat, bangsa dan negaranya. 
q. Setiap orang berhak atas pengakuan, jaminan, perlindungan, dan kepastian hukum yang adil serta perlakuan yang sama di hadapan hukum.

r. Setiap orang berhak untuk bekerja serta mendapat imbalan dan perlakuan yang adil dan layak dalam hubungan kerja.

s. Setiap orang berhak atas status kewarganegaraan.

t. Negara, dalam keadaan apapun, tidak dapat mengurangi hak setiap orang untuk hidup, hak untuk tidak disiksa, hak kemerdekaan pikiran dan hati nurani, hak beragama, hak untuk tidak diperbudak, hak untuk diakui sebagai pribadi di hadapan hukum, dan hak untuk tidak dituntut atas dasar hukum yang berlaku surut.

u. Negara menjamin penghormatan atas identitas budaya dan hak masyarakat tradisional selaras dengan perkembangan zaman dan tingkat peradaban bangsa.

v. Negara menjunjung tinggi nilai-nilai etika dan moral kemanusiaan yang diajarkan oleh setiap agama, dan menjamin kemerdekaan tiap-tiap penduduk untuk memeluk dan menjalankan ajaran agamanya.

w. Perlindungan, pemajuan, penegakan, dan pemenuhan hak asasi manusia adalah tanggung jawab negara, terutama pemerintah.

x. Untuk memajukan, menegakkan dan melindungi hak asasi manusia sesuai dengan prinsip negara hukum yang demokratis, maka pelaksanaan hak asasi manusia dijamin, diatur dan dituangkan dalam peraturan perundang-undangan.

y. Untuk menjamin pelaksanaan Pasal 4 ayat (5) tersebut di atas, dibentuk Komisi Nasional Hak Asasi Manusia yang bersifat 
independen menurut ketentuan yang diatur dengan undang-undang.

z. Setiap orang wajib menghormati hak asasi manusia orang lain dalam tertib kehidupan bermasyarakat, berbangsa, dan bernegara.

aa. Dalam menjalankan hak dan kebebasannya, setiap orang wajib tunduk kepada pembatasan yang ditetapkan dengan undangundang dengan maksud semata-mata untuk menjamin pengakuan serta penghormatan atas hak dan kebebasan orang lain dan untuk memenuhi tuntutan yang adil sesuai dengan pertimbangan moral, nilai-nilai agama, keamanan, dan ketertiban umum dalam suatu masyarakat demokratis. ${ }^{3}$

\section{Pesantren di Indonesia}

1. Sejarah pesantren

Sebagai lembaga pendidikan yang di anggap paling tua di Indonesia, pesantren memiliki akar sejarah yang sangat jelas. Meskipun terdapat perbedaan, dapat dijelaskan bahwa pesantren didirikan pertama kali oleh syaik Maulana Malik Ibrahim atau diberi gelar dengan syeik Maghribi yang berasal dari Gujarat, India dan beliau merupakan pendiri pesantren pertama kali di jawa. ${ }^{4}$

Adapun menurut pendapat Muh. Said dan Juminar Affan mengemukakan bahwa pendiri pesantren pertama kali adalah sunan Ampel atau Raden Rakhmad yang mendirikan pesantren di Kembang kuning, Surabaya. Bahkan Kyai Machrus Ali menjelaskan bahwa selain Raden Rahmad terdapat ulama yang menjelaskan bahwa sunan

${ }^{3}$ Jimly Asshiddiqie, Demokrasi dan Hak Asasi Manusia, (Jakarta: Mahkamah Konstitusi, tt). Doc. Diunduh dalam google tanggal 02 Januari 2016.

${ }^{4}$ Mujamil Qamar, Pesantren: Dari Transformasi Metodologi Menuju Demokrasi Institusi, (Jakarta: Erlangga,2007), hlm. 8. 
gunung jati (Syaikh Syarif Hidayatullah) di Cirebon merupakan pendiri pondok pesantren pertama, sewaktu ia mengasingkan diri dalam rangka berkhalwat untuk mendekatkan diri kepada Allah. ${ }^{5}$

Alwi Shihab dalam bukunya, menegaskan bahwa Syaikh Maulana Malik Ibrahim atau Sunan Gresik adalah orang pertama yang membangun pesantren sebagai tempat mendidik dan menggembleng para santrinya. Tujuannya adalah agar para santri menjadi juru dakwah yang mahir sebelum mereka diterjunkan langsung di masyarakat luas. ${ }^{6}$

2. Pengertian Pesantren

Pesantren menurut kamus besar bahasa Indonesia berarti " asrama tempat para santri atau murid-murid belajar mengaji. Akar kata pesantren adalah santri yaitu suatu istilah yang digunakan bagi orang yang menuntut ilmu agama di lembaga pendidikan tradisional Islam yang berada di lingkungan Jawa dan Madura. ${ }^{7}$

Perkataan pesantren merupakan kata yang berasal dari kata santri, yang diberi awalan pe dan diberi imbuhan an di akhir yang kemudian berarti tempat tinggal para santri. Menurut prof Johns istilah santri berasal bahasa Tamil, yang berarti guru mengaji, sedang C. C Berg berpendapat bahwa istilah tersebut berasal dari istilah shastri, yang dalam bahasa India berarti orang yang tahu buku-buku suci agama Hindu atau seorang sarjana ahli kitab suci agama Hindu. ${ }^{8}$

Istilah pondok barangkali berasal dari pengertian asramaasrama para santri atau tempat tinggal yang dibuat dari bamboo, atau

${ }^{5}$ Ibid.

${ }^{6}$ Alwi Shihab, Islam Inklusif, (Bandung : Mizan, 2002), hal.23.

${ }^{7}$ Ali Anwar, Pembaharuan Pendidikan Di Pesantren Lirboyo Kediri, (Yogyakarta: Pustaka Pelajar, 2011), hlm. 22.

${ }^{8}$ Zamakhsyary Dhofier, Tradisi Pesantren: Studi Pandangan Hidup Kyai Dan Visinya Mengenahi Masa Depan Indonesia, (Jakarta: LP3ES, 2011), hlm. 41 
barangkali berasal dari kata funduq, yang artinya hotel atau asrama. Dari asal usul kata santri pula banyak sarjana berpendapat bahwa lembaga pondok pesantren pada dasarnya adalah lembaga pendidikan keagamaan bangsa Indonesia pada masa menganut agama Hindu Budha yang bernama "mandala" yang diislamkan oleh para kyai. ${ }^{9}$

Terlepas dari mana asal usul kata pesantren itu berasal. Namun yang jelas adalah pesantren merupakan lembaga pendidikan Islam yang merupakan produk asli pribumi Indonesia, yang saat ini merupakan warisan kekayaan bangsa Indonesia yang terus berkembang. Abdur Rahman Assegaf menegaskan bahwa pesantren merupakan lembaga pendidikan yang tertua dan berakar secara nasional bahkan sebelum kolonialisme bangsa Eropa, hingga kini pesantren menjadi bagian integral lembaga pendidikan Islam bagi umat Islam di Indonesia. ${ }^{10}$

3. Elemen-elemen dalam pesantren

Suatu tempat dapat di sebut pesantren jika memiliki elemenelemen berikut ini:

a. Pondok

Sebuah pesantren pada dasarnya adalah sebuah asrama pendidikan Islam tradisional dimana siswanya tinggal bersama dan belajar di bawah bimbingan seorang (atau lebih) guru yang lebih dikenal dengan sebutan kyai. Pondok yang merupakan asrama bagi santri merupakan ciri khas tradisi pesantren yang membedakan dengan system pendidikan tradisional di masjid-

\section{${ }^{9}$ Ibid.} 2005), hlm. 7

${ }^{10}$ Adb. Rahman Assegaf, Politik Pendidikan Nasional, (Yogyakarta: Kurnia Kalam, 
masjid yang berkembang di kebanyakan wilayah Islam di Negara-negara lain. ${ }^{11}$

b. Masjid

Masjid merupakan elemen yang tak dapat dipisahkan dari pesantren dan dianggap sebagai tempat yang paling tepat untuk mendidik para santri, terutama dalam praktik sembahyang lima waktu, khutbah dan pengajian kitab-kitab Islam klasik. Kedudukan masjid sebagai pusat pendidikan dalam tradisi pesantren merupakan manifestasi universalisme dari sistem pendidikan Islam tradisional.

Seorang kyai bila ingin mengembangkan sebuah pesantren, biasanya mendahuluinya dengan membangun masjid terlebih dahulu di dekat rumahnya. Langkah ini biasanya diambil atas perintah dari guru atau kyainya yang menilai bahwa ia layak untuk memimpin dan membina sebuah pesantren. ${ }^{12}$

c. Pengajaran kitab Islam klasik

Pengajaran kitab Islam klasik, terutama karangan-karangan ulama' yang menganut faham syafi'i merupakan satu-satunya bentuk pembelajaran formal pada masa dalam lingkungan pesantren. Tujuan utama dalam pembelajaran ini adalah untuk mendidik calon-calon ulama'. ${ }^{13}$

Biasanya para santri yang bercita-cita sebagai ulama', mengembangkan keahliannya memulai dengan mencoba

\footnotetext{
${ }^{11}$ Zamakhsyary Dhofier, Tradisi Pesantren......, hlm. 81

${ }^{12}$ Ibid...., hlm. 85-86

${ }^{13}$ Ibid...., hlm. 86
} 
mengusai bahasa arab terlebih dahulu di bawah bimbingan guru atau kyainya dengan menggunakan metode sorogan. ${ }^{14}$

d. Santri

Dalam pandangan kepesantrenan, seorang alim ulama' bisa di sebut kyai hanya bila ia telah memiliki pesantren dan santri yang belajar kitab-kitab Islam klasik. Oleh sebab itu santri merupakan elemen penting dalam suatu lembaga pesantren. Menurut tradisi pesantren, santri di bagi menjadi dua kategori yaitu:

1) Santri mukim, yaitu para murid yang berasal dari daerah yang jauh kemudian mereka menetap dalam pesantren.

2) Santri kalong, yaitu murid-murid yang berasal dari desa-desa di sekitar pesantren, dan biasanya mereka tidak menetap dalam pesantren. ${ }^{15}$

e. Kyai

Kyai merupakan elemen yang paling dasar atau esensial dari pesantren. Ia merupakan pendirinya dan sudah sewajarnya bahwa perkembangan suatu pesantren bergantung kepadanya. Menurut asal-usulnya, perkataan kyai dipakai untuk ketiga jenis gelar yang saling berbeda, yaitu:

1) Sebagai gelar kehormatan bagi barang-barang yang dianggap keramat, contohnya "Kyai Garuda Kencana" dipakai untuk sebutan kereta emas yang ada di keraton Yogyakarta.

2) Gelar kehormatan untuk orang-orang tua pada umumnya.

${ }^{14}$ Sorogan merupakan metode pembelajaran dengan mengupayakan menampilkan keahlian di depan kyai, para santri mencoba membaca redaksi arab di depan guru, dan beliau menyimaknya.

${ }^{15}$ Zamakhsyary Dhofier, Tradisi Pesantren....., hlm. 89 
3) Gelar yang di berikan oleh masyarakat kepada seorang ahli agama Islam yang memiliki atau menjadi pemimpin pesantren dan mengajarkan kitab-kitab Islam klasik kepada para santrinya. ${ }^{16}$

4. Tipologi pesantren

Menurut Abd. Muin sebagai mana dikutip dari Ali Anwar, membagi pesantren kedalam tiga tipologi, yaitu:

a. Pesantren salafiyyah yang dicirikan sebagai pesantren yang memfokuskan pada tafaqquh fi ad-din, pengkajian kitab-kitab klasik dengan menggunakan metode bandongan, sorogan maupun klasikal.

b. Pesantren khalafiyyah adalah pesantren yang telah mengadopsi system pendidikan klasikal dengan kurikulum yang tertata dan mengintegrasikan pengetahuan umum, baik dalam bentuk madrasah sebagai sekolah umum yang berciri khas Islam maupun sekolah umum itu sendiri.

c. Pesantren kombinasi yaitu pesantren yang memadukan ciri-ciri pesantren salafiyyah dan khalafiyyah. ${ }^{17}$

Hal ini memiliki sedikit perbedaan dalam segi penjelasan dengan yang telah di jabarkan oleh departemen Agama tentang tipologi pesantren di Indonesia, walaupun dalam segi pembagian cenderung sama, yaitu:

a. Pesantren salafiyyah yaitu pesantren yang hanya menyelenggarakan atau mengutamakan pengajian kitab dan tidak menyelenggarakan pendidikan formal

${ }^{16}$ Ibid....., hlm. 93

${ }^{17}$ Ali Anwar, Pembaharuan Pendidikan Di Pesantren hlm. 28 
b. Pesantren khalafiyyah atau asriyyah yaitu pesantren yang hanya menyelenggarakan atau mengutamakan pendidikan formal.

c. Pesantren kombinasi adalah pesantren yang menyelenggarakan pendidikan formal dan pengkajian kitab. ${ }^{18}$

\section{Isu Pelanggaran HAM dalam Pesantren}

\section{Pelanggaran HAM}

Menurut UU no 39 Tahun 1999 tentang HAM, menyatakan bahwa yang di maksud dengan Pelanggaran HAM adalah setiap perbuatan seseorang atau kelompok orang termasuk aparat negara baik disengaja atau kelalaian yang secara hukum mengurangi, menghalangi, membatasi, dan atau mencabut Hak Asasi Manusia seseorang atau kelompok orang yang dijamin oleh Undang-Undang ini, dan tidak didapatkan, atau dikhawatirksn tidak akan memperoleh penyelesaian hukum yang adil dan benar, berdasarkan mekanisme hukum yang berlaku.

Dengan demikian pelanggaran HAM merupakan tindakan pelanggaran kemanusiaan baik dilakukan oleh individu maupun oleh institusi negara atau institusi lainnya terhadap hak asasi individu lain tanpa ada dasar atau alasan yuridis dan alasan rasional yang menjadi pijakanya.

Menurut UU no 26 tahun 2000 sesuai dengan pasal 7 tentang pengadilan HAM, menjelaskan bahwa pelanggaran hak asasi manusia yang dikategorikan berat adalah:

a. Kejahatan genosida

b. Kejahatan terhadap kemanusiaan.

${ }^{18}$ Ibid. baca juga Dirjen Pendis, Statistik Pendidikan Agama Dan Keagamaan Tuhun Pelajaran 2006-2007, (Jakarta: Dirjen Depag RI, 2007), hlm. 146. 
Yang dimaksud dengan Kejahatan genosida adalah setiap perbuatan yang dilakukan dengan maksud untuk menghancurkan atau memusnahkan seluruh atau sebagian kelompok bangsa, ras, kelompok etnis, kelompok agama, dengan cara:

a. Membunuh anggota kelompok;

b. Mengakibatkan penderitaan fisik atau mental yang berat terhadap anggota-anggota kelompok;

c. Menciptakan kondisi kehidupan kelompok yang akan mengakibatkan kemusnahan secara fisik baik seluruh atau sebagiannya;

d. Memaksakan tindakan-tindakan yang bertujuan mencegah kelahiran di dalam kelompok; atau

e. Memindahkan secara paksa anak-anak dari kelompok tertentu ke kelompok lain.

Adapun yang dimaksud dengan Kejahatan terhadap kemanusiaan adalah salah satu perbuatan yang dilakukan sebagai bagian dari serangan yang meluas atau sistematik yang diketahuinya bahwa serangan tersebut ditujukan secara langsung terhadap penduduk sipil, berupa:

a. Pembunuhan;

b. Pemusnahan;

c. Perbudakan;

d. Pengusiran atau pemindahan penduduk secara paksa;

e. Perampasan kemerdekaan atau perampasan kebebasan fisik lain secara sewenang-wenang yang melanggar (asas-asas) ketentuan pokok hukum internasional;

f. Penyiksaan; 
g. Perkosaan, perbudakan seksual, pelacuran secara paksa, pemaksaan kehamilan, pemandulan atau sterilisasi secara paksa atau bentuk-bentuk kekerasan seksual lain yang setara;

h. Penganiayaan terhadap suatu kelompok tertentu atau perkumpulan yang didasari persamaan paham politik, ras, kebangsaan, etnis, budaya, agama, jenis kelamin atau alasan lain yang telah diakui secara universal sebagai hal yang dilarang menurut hukum internasional;

i. Penghilangan orang secara paksa; atau

j. Kejahatan apartheid.

2. Budaya ta'zir dan isu pelanggaran HAM

Ta'zir secara bahasa berarti menolak dan mencegah atau melarang. ${ }^{19}$ Adapun pengertian secara istilah adalah larangan atau perintah tentang suatu hal yang tidak dirumuskan secara pasti termasuk sanksinya dan pelaksanaan hukumannya bergantung pada pihak penguasa. $^{20}$

Pada sebuah pondok pesantren yang bertipologi salafiyyah, biasanya menggunakan istilah ta'zir untuk memberikan hukuman kepada santri yang melanggar aturan yang telah di tentukan oleh pengasuh ataupun pengurus pondok pesantren. Jenis ta'zir bisa bermacam-macam tergantung apa aturan yang telah dilanggar oleh para santri.

Penentuan ta'zir pada setiap pondok pesantrenpun berbedabeda sesuai dengan kebijakan pengasuhnya, walaupun pondok pesantren mempunyai tipologi yang sama. Sebagai contoh pada

${ }^{19}$ Idris Ahmad, Fiqih Syafi'I, (tt: Karya Indah, 2006), hlm. 632

20 Amrullah Ahmad, Dimensi Hukum Islam dalam Sistem hukum Nasional: Mengenang 65 Tahun Prof. Dr. h. Bustanul Arifin, S.H, (Jakarta: Gema Insani Press, 1996), hlm. 158 
pondok pesantren tertentu memberlakukan hukuman penggundulan rambut bagi santri yang terbukti mencuri. ${ }^{21}$ Pada pondok tertentu memberikan ta'zir lari mengelilingi lapangan dikarenakan terlambat mengikuti kegiatan pengajian madrasah diniyah.

Bagi sebagian pondok pesantren yang menerapkan ta'zir berupa hukuman fisik seperti mencambuk atau menjewer telinga sampai merah, di sinyalir bagi sebagaian aktifis HAM sebagai suatu bentuk pelanggaran HAM yang harus ditinggalkan oleh pesantren. Mereka berpendapat bahwa pemberian hukuman untuk efek jera berupa hukuman fisik tidak memperbaiki keadaan, lebih baik memberikan hukuman berupa bentuk lain yang tidak mencederai fisik sebagai bentuk pembelajaran karakter.

Disisi lain di jelaskan dalam salah satu kaidah cabang dalam kaidah fiqhiyyah yaitu "al-ridla bi asy-syai' ridla bima yatawalladu minhu" yang berarti "Rela dengan sesuatu berarti rela dengan apa saja yang tibul dari sesuatu tersebut". Hal ini yang menjadi patokan bagi para kyai dan para santrinya dalam menjalankan peraturan dalam sebuah pondok pesantren. Memang ta'zir diperlukan dalam peraturan pesantren guna memberikan pendidikan tentang kedisiplinan bagi para santrinya. Namun yang jadi perbincangan hingga sekarang adalah apakah bentuk hukuman fisik bias di hindari dengan mengganti bentuk hukuman lain.

3. Wacana pelanggaran HAM dalam hukuman cambuk dalam pesantren

Pada tahun kemaren tepatnya tahun 2014, dunia pendidikan sempat digegerkan tentang adanya hukuman cambuk yang di

${ }^{21}$ Sebuah contoh ta'zir yang di jalankan pada suatu pondok pesantren salafi di Mranggen kabupaten Demak Jawa Tengah. 
berlakukan oleh salah satu pondok pesantren di Jombang yaitu pondok pesantren Al-Urawatul Wutsqo kepada ketiga santrinya.

Video yang di buat pada tahun 2009 namun beredar pada tahun 2014 ini mempertontonkan santri yang terkena hukuman cambuk sebanyak 35 kali yang dikenakan kepada tiga santri dengan menutup matanya terlebih dahulu dan diikat dalam sebuah pohon. Hal ini dilakukan oleh pengurus pesantren pada santri yang melakukan pelanggaran berat seperti minum minuman keras dan berzina. Satu per satu ketiga santri menjalani hukuman cambuk menggunakan 2 buah rotan. ${ }^{22}$

Menteri Agama Lukman Hakim Saifuddin mengimbau pengurus pensantren untuk tidak lagi menggunakan kekerasan seperti hukuman cambuk kepada para santrinya. Ia menjelaskan saat rapat koordinasi di kantor Kementerian Koordinator Pembangunan Manusia dan Kebudayaan, Kamis, 10 Desember 2014 bahwa "Intinya, jangan sampai itu melukai fisik karena itu amat tidak baik dalam konteks pendidikan,"

Meski tidak mendukung dengan hukuman kekerasan, Lukman tidak dapat melarang penggunaan kekerasan dalam pesantren. Menurut dia, pemerintah tidak punya kewenangan memaksa pesantren. Musababnya, kata Lukman, masing-masing pesantren memiliki otonominya sendiri. ${ }^{23}$

Menurut hemat penulis tentang ta'zir berupa hukuman cambuk, memanglah harus ditiadakan mengingat kasus dalam pesantren tersebut memberlakukan hukum cambuk sebanyak 35 kali dengan

22 http://news.liputan6.com/read/2147030/hukuman-cambuk-di-pesantren diambil dalam google pada tanggal 02 Januari 2016. Januari 2016.

${ }^{23} \mathrm{http}: / /$ nasional.tempo.co/read/news di ambil dalam google pada tanggal 02 
dua rotan sangat tidak berperi kemanusian karena menyebabkan luka fisik yang sangat serius. Hal ini dapat dikategorikan dalam pelanggaran ham berat pada jenis yang kedua yaitu kejahatan terhadap kemanusiaan pada poin $\mathrm{f}$ yaitu penyiksaan yang termaktub dalam UU no 26 tahun 2000 tentang pengadilan HAM.

Selain bertentangan dengan UU no 26 tahun 2000 hal ini juga melanggar apa yang telah dirumuskan dalam Mahkamah Konstitusi pada poin j yaitu "Setiap orang berhak untuk bebas dari penyiksaan atau perlakuan yang merendahkan derajat martabat manusia dan berhak memperoleh suaka politik dari negara lain". Jika hukuman seperti ini berkelanjutan bukan tidak mungkin pondok pesantren tersebut akan mendapatkan sanksi politik atau berurusan dengan pihak berwajib karena telah melanggar UU yang telah dirumuskan.

\section{E. Simpulan}

Hak asasi manusia adalah hak dasar yang secara kodrati melekat pada diri manusia, bersifat universal dan langgeng, oleh karena itu harus dilindungi, dihormati, dipertahankan, dan tidak boleh diabaikan, dikurangi, atau dirampas oleh siapapun. Hak Asasi Manusia di Indonesia di lindungi oleh UU dan bersumber serta bermuara pada Pancasila. Pelanggaran HAM adalah setiap perbuatan baik disengaja atau kelalaian yang secara hukum mengurangi, menghalangi, membatasi, dan atau mencabut Hak Asasi Manusia yang dijamin oleh Undang-Undang namun tidak didapatkan, atau dikhawatirksn tidak akan memperoleh penyelesaian hukum yang adil dan benar, berdasarkan mekanisme hukum yang berlaku.

Pesantren merupakan lembaga pendidikan yang tertua dan berakar secara nasional bahkan sebelum kolonialisme bangsa Eropa. Unsur- 
unsur terpenting dalam pesantren adalah Masjid, pondok, pengkajian kitab klasik, santri dan kyai. Terdapat 3 tipologi pesantren di Indonesia yaitu salafiyyah, khalafiyyah dan kombinasi. Ta'zir adalah larangan atau perintah tentang suatu hal yang tidak dirumuskan secara pasti termasuk sanksinya dan pelaksanaan hukumannya bergantung pada pihak penguasa. Pada sebuah pondok pesantren yang bertipologi salafiyyah, biasanya menggunakan istilah ta'zir untuk memberikan hukuman kepada santri yang melanggar aturan.

Tentang ta'zir berupa hukuman cambuk, memanglah harus ditiadakan karena sangat tidak berperi kemanusian karena menyebabkan luka fisik yang sangat serius. Hal ini dapat dikategorikan dalam pelanggaran HAM berat pada jenis yang kedua yaitu kejahatan terhadap kemanusiaan pada poin $\mathrm{f}$ yaitu penyiksaan yang termaktub dalam UU no 26 tahun 2000 tentang pengadilan HAM.

\section{DAFTAR PUSTAKA}

Ahmad, Amrullah, Dimensi Hukum Islam dalam Sistem hukum Nasional: Mengenang 65 Tahun Prof. Dr. h. Bustanul Arifin, S.H, Jakarta: Gema Insani Press, 1996.

Ahmad, Idris, Fiqih Syafi'I, tt: Karya Indah, 2006.

Anwar, Ali, Pembaharuan Pendidikan Di Pesantren Lirboyo Kediri, Yogyakarta: Pustaka Pelajar, 2011.

Assegaf, Adb. Rahman, Politik Pendidikan Nasional, Yogyakarta: Kurnia Kalam, 2005.

Asshiddiqie, Jimly, Demokrasi dan Hak Asasi Manusia, Jakarta: Mahkamah Konstitusi, tt. 
Dhofier, Zamakhsyary, Tradisi Pesantren: Studi Pandangan Hidup Kyai Dan Visinya Mengenahi Masa Depan Indonesia, Jakarta: LP3ES, 2011.

Dirjen Pendis, Statistik Pendidikan Agama Dan Keagamaan Tuhun Pelajaran 2006-2007, Jakarta: Dirjen Depag RI, 2007.

Gonggong, Anhar, Dkk, Sejarah Pemikiran Hak-Hak Asasi Manusia Di Indonesia, Jakarta: Depdikbud, 1995.

http://nasional.tempo.co/read/news di ambil dalam google pada tanggal 02 Januari 2016.

http://news.liputan6.com/read/2147030/hukuman-cambuk-di-pesantren diambil dalam google pada tanggal 02 Januari 2016.

http://www.zonasiswa.com/2014/07/sejarah-hak-asasi-manusia-ham.html dalam google diambil tanggal 30 Desember 2015.

https://edudetik.wordpress.com/2014/05/24/makalah-ham-pengertianpenyebab-dan-contoh-kasus-pelanggaran-ham/ dalam google diambil pada tanggal 02 Januari 2016.

Kaelan, Pendidikan Pancasila, Edisi reformasi, Yogyakarta: Paradigma, 2010.

Qamar, Mujamil, Pesantren: Dari Transformasi Metodologi Menuju Demokrasi Institusi, Jakarta: Erlangga, 2007.

Shihab, Alwi, Islam Inklusif, Bandung : Mizan, 2002. 